\title{
ISOLASI DAN IDENTIFIKASI BAKTERI GRAM NEGATIF PADA LUKA IKAN MASKOKI (Carassius auratus) AKIBAT INFESTASI EKTOPARASIT Argulus sp. \\ ISOLATION AND IDENTIFICATION GRAM NEGATIVE BACTERIA AT LESSIONS OF GOLD FISH (Carassius auratus) BY INFESTATION ECTOPARASITE Argulus sp.
}

\author{
Kismiyati, Sri Subekti, R. Wahid Nur Yusuf dan Rahayu Kusdarwati \\ Fakultas Perikanan dan Kelautan Universitas Airlangga \\ Kampus C Mulyorejo - Surabaya, 60115 Telp. 031-5911451
}

\begin{abstract}
One of them is the problem of disease Argulus sp. is ektoparasite which often attacked in activity of good conducting of sea water and also freshwater. Argulus sp. attacking at part of fin, husk, gill and entire all its body exterior of him. attacked by fish is Argulus sp. will seen is thin, often rub body and arise red pock which later can generate secondary infection.

Utilize to prove the existence of bacterium which emerge effect of lession (secondary infection) which because of bite of Argulus sp. that is by identifying bacterium and biochemical test. Media which used in identifying bacterium for example that is TSA (Tryptic Soy Agar), TSIA (Triple Soy Iron Agar), MIO (Motility Indol Ornithin), O/F medium (Oksidative/Fermentative), sugar test medium (maltosa, laktosa, arabinosa, inositol, manitol, sukrosa).

Target of this research is to know the existence of gram negative bacterium and gram negative bacterium any kind of which is found at fish hurt of gold fish (Carassius auratus) effect of infestation by ectoparasite Argulus sp.

Research which is use descriptive method. That is with infestation of Argulus sp. into containing aquarium of gold fish counted 1 tail and Argulus sp. counted 5, 10, 15, 20 tail. After Argulus sp. patch all at gold fish is later then perceived until gold fish arise lession effect of bite of Argulus sp. is afterwards identifyed by bacterium to know the bacterium that were formed on gold fish lesions.

The result showed that the lesions of gold fish, isolation at TSA medium and identified by biochemical test to diagnose bacteriums found on gold fish lession. Identifications of the three gram negative bacterium as follow : Aeromonas hydrophilla, Pseudomonas flourescens, Flexibacter columnaris while for the Edwardsiella tarda was not be found in this study.
\end{abstract}

Key words : gold fish, parasite, gram negative bacteria

\section{Pendahuluan}

Usaha perikanan di Indonesia saat ini telah berkembang dengan pesat terutama dalam bidang budidaya, baik sektor ikan hias maupun ikan konsumsi. (Lingga dan Susanto, 2003). Indonesia memiliki perairan tawar yang sangat luas dan berpotensi besar untuk usaha berbagai macan jenis ikan air tawar. Ikan hias air tawar merupakan salah satu alternatif usaha untuk menjalankan perekonomian yang banyak menghasilkan devisa. Salah satu ikan hias yang cukup terkenal di kalangan penggemar ikan adalah maskoki (Effendi, 1993).

Seiring dengan meningkatnya usaha dalam budidaya ikan Maskoki, semakin besar juga tantangan yang akan dihadapi oleh para pelaku budidaya ikan hias pada umumnya dan khususnya ikan Maskoki untuk memenuhi kebutuhan tersebut. Timbulnya serangan penyakit merupakan hasil interaksi yang tidak seimbang antara lingkungan, kondisi inang (ikan) dan pathogen (penyakit). Interaksi yang tidak seimbang ini menyebabkan stres pada ikan, sehingga mekanisme pertahanan tubuh menjadi lemah dan akhirnya mudah diserang penyakit (Prajitno, 2005).

Argulus sp. merupakan salah satu jenis ektoparasit yang sering menyerang dalam kegiatan budidaya baik air tawar maupun air laut. Argulus sp. menyerang pada bagian sirip, kulit, insang dan seluruh bagian luar tubuh inang. Ikan yang terserang Argulus sp. akan terlihat kurus, sering menggosokkan badan dan timbul bercak merah yang nantinya dapat menimbulkan infeksi sekunder (Lingga dan Susanto, 2003).

Menurut (Prasetya dkk, 2004) serangan parasit lebih sering mematikan pada beberapa ikan muda yang biasanya berukuran kecil karena belum berkembangnya sistem pertahanan tubuh. Selain menginfeksi ikan, Argulus sp. juga dapat berperan sebagai vektor bagi virus atau bakteri yang sering menyebabkan penyakit pada ikan (Afrianto dan Liviawati, 1992). Faktor yang menyebabkan timbulnya penyakit antara lain disebabkan oleh mikroorganisme seperti bakteri, jamur dan virus. 
Sementara faktor kualitas air yang buruk, pakan, oksigen menurun dapat mempengaruhi adanya penyakit (Irianto, 2005).

Penelitian ini bertujuan untuk mengetahui jenis-jenis bakteri gram negatif yang ditemukan pada luka ikan Maskoki (Carassius auratus) akibat infestasi oleh ektoparasit Argulus sp.

Manfaat yang diharapkan dari penelitian ini adalah dengan mengetahui jenis bakteri gram negatif apa saja yang sering ditemukan pada ikan Maskoki (Carassius auratus) akibat infestasi yang disebabkan oleh ektoparasit Argulus sp., sehingga dapat memberikan informasi dan manfaat bagi para pelaku budidaya ikan untuk menanggulangi serangan ektoparasit Argulus sp.

\section{Materi dan Metode Penelitian}

Tempat dan waktu

Penelitian dilaksanakan di rumah dengan alamat J1. Sutorejo Tengah 13/23 dan di Laboratorium Bakteriologi Balai Karantina Ikan Juanda Surabaya. Penelitian dilakukan selama satu bulan yaitu pada tanggal 22 Desember 2008 sampai 22 Januari 2009.

\section{Bahan penelitian}

Ikan Maskoki (Carassius auratus) dengan panjang total $10 \mathrm{~cm}$ yang berasal dari pedagang ikan hias yang berada di desa Bangoan Tulungagung. Argulus sp. yang berasal dari Tulungagung.

TSA (Tryptic Soy Agar), TSIA (Triple Soy Iron Agar), MIO (Motility Indol Ornithin), media O/F (Oksidatif/Fermentatif), media uji gula (maltosa, laktosa, arabinosa, inositol, manitol, sukrosa), aquades steril.

\section{Alat penelitian}

Alat penelitian meliputi akuarium (ukuran $45 \times 25 \times 25 \mathrm{~cm}$ ) sebanyak 20 buah, pH paper, termometer, beacker glass, jaring ikan, selang aerasi, batu aerasi, filter, petridish, jarum ose, pembakar bunsen, pipet tetes, autoclave, mikroskop, timbangan analitik, amoniak test-kit, beaker glass.

Metode penelitian yang dilakukan adalah dengan menggunakan metode deskriptif yang bertujuan untuk mendeskripsikan secara sistematis, faktual dan akurat terhadap suatu populasi atau daerah tertentu, mengenai sifat atau faktor tertentu (Sudjana, 2002). Hasil dari penelitian disajikan dengan menggunakan metode deskriptif.
Penelitian pendahuluan bertujuan untuk menentukan perlakuan yang diberikan dan lamanya waktu penelitian. Perlakuan yang diberikan yaitu banyaknya Argulus sp. yang berbeda untuk setiap perlakuan.

Penelitian pendahuluan dilakukan dengan cara ikan maskoki sebanyak 10 ekor yang masingmasing diinfestasi Argulus sp. sebanyak 25 ekor pada beaker glass selama 15 menit. Hasil pengamatan pada penelitian pendahuluan ikan maskoki yang terinfestasi 5 Argulus sp. sudah terdapat luka, sedangkan ikan maskoki yang terinfestasi 19 Argulus sp. mengalami kematian sehingga ditetapkan batas terendah jumlah Argulus sp. yang diinfestasi adalah 5 ekor Argulus sp. dan batas tertingginya yaitu 20 ekor dengan kelipatan 5 .

Lama perlakuan pada penelitian utama adalah selama 7 hari yang ditetapkan berdasarkan kondisi ikan yang terinfestasi Argulus sp. yaitu sampai ikan terdapat luka, sisik terkelupas sehingga untuk lebih meyakinkan adanya luka ikan maskoki maka isolasi pada luka dilakukan pada hari ke-8.

\section{Persiapan}

Alat yang digunakan dalam penelitian seperti akuarium, batu aerasi dan selang aerasi dibersihkan terlebih dahulu dengan cara dicuci menggunakan sabun hingga bersih kemudian direndam ke dalam larutan khlorin 12 ppm dan dikeringkan di bawah sinar matahari.

Persiapan sarana penelitian adalah persiapan akuarium berupa pengisian air dengan volume air sebanyak 20 liter dan dilakukan pemberian aerasi selama 24 jam sebelum digunakan. Tujuan dari persiapan akuarium adalah agar ikan yang dimasukkan tidak stres.

Menurut Volk dan Wheeler (1993), metode yang lazim digunakan untuk mensterilkan media adalah menempatkannya di dalam autoclave, dengan menggunakan uap bertekanan untuk menaikkan suhu media yang disterilkan sampai suatu taraf yang mematikan semua bentuk kehidupan. Sterilisasi media dengan autoclave menggunakan suhu $121^{0} \mathrm{C}$ pada tekanan uap 15 lb/in2 selama 15-20 menit. Media gula merupakan salah satu media yang tidak dapat di sterilkan dengan menggunakan autoclave karena media gula pada suhu dan tekanan tinggi akan menjadi rusak. Sterilisasi media gula menggunakan aquades yang dipanaskan pada gelas ukur, kemudian media gula yang telah diletakkan pada tabung reaksi dimasukkan pada aquades yang telah dipanaskan tersebut. 
Ikan maskoki (Carassius auratus) yang telah diperoleh, dimasukkan dan diadaptasikan terlebih dahulu ke dalam akuarium penampungan yang telah diberi aerasi selama 24 jam. Tiap 5 ekor ikan Maskoki diinfestasi oleh 5, 10, 15, 20 ekor Argulus sp. dengan cara infestasi buatan. Setelah itu ikan Maskoki yang telah diinfestasi buatan tersebut dimasukkan kembali ke dalam akuarium perlakuan. Infestasi buatan adalah metode penempelan Argulus sp. pada ikan Maskoki secara buatan dengan cara ikan dimasukkan ke dalam Beaker glass berisi air sebanyak $400 \mathrm{ml}$, kemudian Argulus sp. dimasukkan ke dalam Beaker glass dengan jumlah yang disesuaikan dengan masing-masing perlakuan. Kemudian dilakukan pengamatan selama 15 menit, ikan yang sudah terinfeksi oleh Argulus sp. dimasukkan kembali ke dalam aquarium perlakuan.

Penelitian ini menggunakan 4 perlakuan, masing-masing perlakuan mendapat 5 kali ulangan.

Perlakuan A : 1 ekor ikan maskoki di infestasi dengan Argulus sp. 5 ekor

Perlakuan B : 1 ekor ikan maskoki di infestasi dengan Argulus sp. 10 ekor

Perlakuan C : 1 ekor ikan maskoki di infestasi dengan Argulus sp. 15 ekor

Perlakuan D : 1 ekor ikan maskoki di infestasi dengan Argulus sp. 20 ekor

Pengamatan dilakukan dengan mengamati luka pada ikan maskoki selama 7 hari. Isolasi dan identifikasi bakteri dilakukan apabila luka sudah diperoleh. Adapun metode isolasi dan identifikasi bakteri adalah sebagai berikut :

Isolasi Bakteri

Isolasi bakteri bertujuan untuk mendapatkan bakteri yang menyerang pada sampel yang diduga terinfeksi bakteri. Sumber isolasi pada ikan adalah semua bagian tubuh yang mengalami kelainan patologi yang diduga disebabkan oleh penyakit bakterial dari bagian tubuh eksternal maupun internal. Isolasi bakteri ini dilakukan dengan menggunakan media agar yang bersifat umum, yaitu media Triptic Soy Agar (TSA) atau Nutrient Agar (NA) (Balai Karantina Ikan, 2000).

Pemurnian Bakteri

Pemurnian ini merupakan kelanjutan dari isolasi bakteri yang bertujuan untuk mengidentifikasi mikroorganisme penyebab penyakit dengan cara mengambil koloni bakteri yang tumbuh dominan atau terbanyak dengan asumsi bahwa bakteri yang dominan tersebut merupakan bakteri penyebab penyakit. Media yang digunakan sama dengan media yang digunakan untuk isolasi bakteri yaitu media TSA (Balai Karantina Ikan, 2000).

Identifikasi bakteri

Identifikasi bakteri meliputi pemeriksaan morfologi, pewarnaan gram, dan uji biokimia antara lain : uji O/F, uji oksidase, uji katalase, uji motilitas, produksi indol, uji TSIA, uji gula. Identifikasi bakteri dilakukan dalam beberapa uji antara lain Pengamatan morfologi koloni bakteri

Pengamatan morfologi koloni bakteri dilakukan setelah mendapatkan biakan murni. Pengamatan ini meliputi warna, bentuk, tepian koloni, elevasi atau permukaan koloni dan struktur dalam koloni.

Pewarnaan gram

Pewarnaan gram bertujuan untuk menentukan apakah bakteri tersebut termasuk di dalam kelompok bakteri gram positif atau kelompok bakteri gram negatif. Cara kerja dari pewarnaan gram yaitu suspensikan bakteri dengan ose, kemudian letakkan pada obyek dan difiksasi, tetesi dengan larutan gram A yang mengandung kristal violet, kemudian tetesi dengan larutan gram $\mathrm{B}$ yang mengandung lugol, tetesi dengan larutan gram $\mathrm{C}$ yang mengandung alkohol, dan yang terakhir tetesi dengan larutan gram D yang mengandung safranin.

Uji katalase

Tujuan uji katalase adalah untuk mengetahui sifat bakteri dalam menghasilkan enzim katalase. Cara kerja dari uji katalase yaitu larutan $\mathrm{H}_{2} \mathrm{O}_{2} 3 \%$ diteteskan pada obyek, kemudian suspensikan koloni bakteri dengan ose.

Uji oksidase

Tujuan uji oksidase adalah untuk mengetahui ada tidaknya enzim oksidase pada bakteri dengan menggunakan paper oksidase yang dapat dilihat perubahan warna yang terjadi pada paper oksidase.

$\mathrm{Uji} \mathrm{O/F}$ (Oksidatif/Fermentatif)

$\mathrm{Uji} \mathrm{O} / \mathrm{F}$ medium (Oksidatif/Fermentatif) bertujuan untuk mengetahui sifat oksidasi atau fermentasi bakteri terhadap glukosa dengan menggunakan dua tabung media yang salah satunya ditutup dengan parafin, sehingga diharapkan di dalam media tidak terdapat udara yang dapat mendukung terjadinya fermentasi.

Uji motilitas dan mroduksi indol

Uji motilitas bertujuan untuk mengetahui apakah bakteri tersebut motil atau tidak dan untuk mengetahui produksi indol dari Tryptophane. Uji ini menggunakan media MIO (Motility Indole Ornitin). 
Uji TSIA (Triple Sugar Iron Agar)

Uji TSIA (Triple Sugar Iron Agar) bertujuan untuk membedakan jenis bakteri berdasarkan kemampuan memecahkan dextrose, laktosa, sukrosa dan pembebasan sulfida, selain itu uji TSIA berfungsi untuk mengetahui apakah bakteri tersebut menghasilkan gas, $\mathrm{H}_{2} \mathrm{~S}$ atau tidak. Media yang digunakan mempunyai dua bagian, yaitu slant (miring) dan butt (tusuk).

Uji gula

Uji gula bertujuan untuk mendeterminasi kemampuan bakteri dalam mendegradasi gula dan menghasilkan asam organik yang berasal dari tiaptiap jenis gula, yaitu glukosa, sukrosa, maltosa, arabinosa, manitol dan inositol.

Parameter penelitian

Parameter utama yang diamati dalam penelitian ini adanya bakteri yang muncul akibat infestasi ektoparasit Argulus sp. pada luka ikan Maskoki (Carassius auratus). Parameter penunjang berupa pengukuran $\mathrm{pH}$, suhu dan kandungan oksigen terlarut (DO).

\section{Hasil dan Pembahasan}

Penelitian ini dilakukan dengan menginfestasikan Argulus sp. pada ikan Maskoki dan mengamati luka yang diakibatkan infestasi ektoparasit Argulus sp. selama 7 hari. Hal ini berguna untuk dapat melanjutkan penelitian tersebut dengan melakukan isolasi dan identifikasi terhadap luka pada ikan tersebut. Pengamatan yang dilakukan dalam penelitian ini meliputi pengamatan secara visual melihat tanda-tanda kerusakan pada bagian tubuh ikan yang telah terinfestasi oleh Argulus sp.

Ikan maskoki yang terdapat luka pada bagian tubuhnya akan dilakukan isolasi pada media TSA dan di inkubasi pada suhu kamar selama 24 jam. Setelah proses isolasi selama 24 jam selasai dan timbul berbagai macam koloni bakteri, kemudian dilakukan pemurnian terhadap bakteri yang terlihat dominan pada media TSA yang telah dibuat untuk penanaman tersebut. Pemurnian terhadap koloni yang dominan dilakukan agar diperoleh biakan dari bakteri sehingga dapat diketahui jenis dari bakteri tersebut.

Hasil identifikasi bakteri gram negatif pada luka akibat infestasi Argulus sp.

Identifikasi bakteri pada luka ikan maskoki (Carassius auratus) akibat infestasi ektoparasit Argulus sp. dilakukan di Laboratorium Balai Karantina Ikan Juanda. Metode konvensional meliputi pemeriksaan morfologi, pewarnaan gram dan uji biokimia meliputi uji O/F, uji oksidase, uji katalase, uji motilitas, produksi indol, uji TSIA, dan uji gula (Austin and Austin, 1999). Hasil penelitian ini didapatkan tiga bakteri antara lain yaitu : Aeromonas hydrophilla, Pseudomonas flourescens, Flexibacter columnaris sedangkan untuk Edwardsiella tarda tidak ditemukan pada identifikasi bakteri.

Hasil uji biokimiawi pada penelitian ini dapat dilihat pada Tabel 2.

Tabel 2. Uji biokimiawi Aeromonas hydrophila

\begin{tabular}{|l|c|}
\hline \multicolumn{1}{|c|}{ Parameter } & Hasil \\
\hline Koloni : 124 & \\
- Warna & Krem \\
- Bentuk Elevasi & Cembung \\
- Tepi & Rata \\
- Struktur dalam & Transparan \\
Motilitas & + \\
Memproduksi : & \\
- Indol & + \\
- Oksidase & + \\
- Katalase & + \\
Arabinosa & - \\
Glukosa & + \\
Inositol & - \\
Laktosa & + \\
Sukrosa & + \\
Manitol & + \\
TSIA & K/A, G, $\mathrm{H}_{2} \mathrm{~S}$ \\
O/F & $\mathrm{F}$ \\
\hline
\end{tabular}

ket : TSIA - K/A; G; $\mathrm{H}_{2} \mathrm{~S}=$ reaksi Alkalin/Asam; terdapat gas; terdapat $\mathrm{H}_{2} \mathrm{~S}$

$\mathrm{O} / \mathrm{F}-\mathrm{F}=$ bersifat Fermentatif

Hasil uji biokimiawi pada penelitian ini dapat dilihat pada Tabel 3 .

Tabel 3. Uji biokimiawi Pseudomonas fluorescens

\begin{tabular}{|l|c|}
\hline \multicolumn{1}{|c|}{ Parameter } & Hasil \\
\hline Koloni : 124 & \\
- Warna & Putih Kekuningan \\
- Bentuk Elevasi & Cembung \\
- Tepi & Rata \\
- Struktur dalam & Transparan \\
Motilitas & + \\
Memproduksi : & \\
- Indol & - \\
- Oksidase & + \\
- Katalase & + \\
Arabinosa & + \\
Glukosa & + \\
Inositol & + \\
Laktosa & + \\
Sukrosa & + \\
Manitol & + \\
TSIA & $\mathrm{K} / \mathrm{K}, \mathrm{H}_{2} \mathrm{~S}$ \\
O/F & $\mathrm{O}$ \\
\hline
\end{tabular}


ket : TSIA - K/A; G; $\mathrm{H}_{2} \mathrm{~S}$ = reaksi Alkalin/Asam; terdapat gas; terdapat $\mathrm{H}_{2} \mathrm{~S}$

$\mathrm{O} / \mathrm{F}-\mathrm{F}=$ bersifat Fermentatif

Hasil uji biokimiawi pada penelitian Flexibacter columnaris dapat dilihat pada Tabel 4. Tabel 4. Uji biokimiawi Flexibacter columnaris

\begin{tabular}{|l|c|}
\hline \multicolumn{1}{|c|}{ Parameter } & Hasil \\
\hline Koloni : 124 & \\
- Warna & Hijau Kekuningan \\
- Bentuk Elevasi & Tipis \\
- Tepi & Rata \\
- Struktur dalam & Transparan \\
Motilitas & + \\
Memproduksi : & - \\
- Indol & + \\
- Oksidase & + \\
- Katalase & - \\
Arabinosa & - \\
Glukosa & - \\
Inositol & - \\
Laktosa & - \\
Sukrosa & - \\
Manitol & K/K, G \\
TSIA & O \\
O/F & \\
\hline
\end{tabular}

ket : TSIA - K/A; G; $\mathrm{H}_{2} \mathrm{~S}$ = reaksi Alkalin/Asam; terdapat gas; terdapat $\mathrm{H}_{2} \mathrm{~S}$

$\mathrm{O} / \mathrm{F}-\mathrm{F}=$ bersifat Fermentatif

Kualitas air selama penelitian yaitu suhu air berkisar antara $26-28^{\circ} \mathrm{C}, \mathrm{pH} 7$, amoniak berkisar antara 0-0,003 mg/l dan oksigen terlarut 6 $\mathrm{mg} / \mathrm{l}$.

Hasil pengamatan tingkah laku ikan maskoki yang tidak diinfestasi Argulus sp. menunjukkan gerakan tubuh yang normal dengan nafsu makan yang tetap. Kondisi tubuh ikan maskoki tersebut sehat tanpa terdapat luka baik pada permukaan tubuh maupun sirip ikan, sedangkan yang diinfestasi Argulus sp. menunjukkan gerakan tubuh yang tidak normal seperti menggesek-gesekkan tubuh pada kaca akuarium, selain itu ikan sering berada di dasar perairan serta nafsu makannya juga menurun, juga terdapat beberapa ikan maskoki yang berada di air permukaan pada akhir pengamatan. Gejala klinis yang terjadi yaitu terjadi pendarahan pada sirip ekor, kondisi tubuh terdapat luka baik pada permukaan tubuh maupun sirip ikan.

Ektoparasit Argulus sp. menyerang ikan maskoki dengan menghisap darah, sehingga menyebabkan ikan stress, dan terjadi perubahan tingkah laku pada ikan maskoki tersebut. Perubahan tingkah laku pada ikan antara lain berenang pasif dan selera makan menjadi turun. Hal ini terjadi karena infestasi Argulus sp. yang menyerang ikan maskoki menimbulkan bekas luka akibat alat penghisap dari Argulus sp. yang kemudian akan timbul ulcer, dalam jangka waktu yang agak lama akan terjadi pendarahan dan kerusakan jaringan pada bagian luar dari kulit ikan yang terserang Argulus sp. tersebut. Kemudian terjadi inflamasi. Argulus sp. mengeluarkan simultaneously releasing toxic anticoagulant substances yang berfungsi untuk mencegah pambekuan darah ikan yang telah dihisapnya (Karvonen et al., 1997). Selain zat di atas, Argulus sp. juga mengeluarkan digestive enzyme ke dalam tubuh ikan yang diserang oleh Argulus sp. tersebut sehingga memicu munculnya bakteri oportunistik bakteri pada luka akibat serangan dari Argulus sp. tersebut (Yildiz and Kumantas, 2002).

Hubungan antara infestasi Argulus sp. dan infeksi bakteri gram negatif dapat dikatakan berkaitan erat, hal tersebut diakibatkan adanya interaksi antara satu dengan yang lainnya. Infestasi Argulus sp. pada tubuh ikan maskoki akan menimbulkan luka yang dapat memicu munculnya bakteri tersebut di atas. Luka bekas dari infestasi Argulus sp. akan banyak ditumbuhi oleh bakteri gram negatif karena salah satu sifat dari bakteri gram negatif tersebut adalah dapat mencerna hemoglobin dan gelatin yang terdapat pada luka akibat infestasi ektoparasit Argulus sp. sehingga banyak bakteri yang muncul pada lokasi di sekitar luka yang terdapat pada tubuh ikan maskoki tersebut.

Bakteri gram negatif yang muncul pada luka akibat infestasi ektoparasit Argulus sp. tersebut adalah kebanyakan dari genus Aeromonas, Pseudomonas, dan Flexibacter. Selain bakteri gram negatif juga terdapat jamur seperti Saprolegnia sp. dan Achylya sp. sehingga dapat menyebabkan kematian massal pada ikan. (Handajani, 2005).

\section{Kesimpulan}

Terdapat bakteri gram negatif pada luka ikan Maskoki (Carassius auratus) akibat infestasi ektoparasit Argulus sp. Bakteri gram negatif yang ditemukan pada luka ikan Maskoki (Carassius auratus) akibat infestasi ektoparasit Argulus sp. adalah Aeromonas hydrophilla, Pseudomonas flourescent dan Flexibacter columnaris. 
Perlu adanya penelitian lebih lanjut mengenai adanya bakteri lain yang mungkin ditemukan pada luka ikan Maskoki (Carassius auratus) akibat infestasi ektoparasit Argulus sp.

\section{Daftar Pustaka}

Afrianto E. dan E. Liviawati. 1992. Pengendalian Hama dan Penyakit. Kanisius. Yogyakarta. 89 hal.

Austin B. and D. A. Austin. 1999. Bacterial Fish Pathogens : Disease of Farmed And Wild Fish. Praxis Publishing. Chichester.

Balai Karantina Ikan. 2000. Prosedur Pemeriksaan Bakteri. Dinas Kelautan dan Perikanan. Jakarta.

Effendy, H. 1993. Mengenal Beberapa Jenis Koi. Kanisius. Yogyakarta.
Handajani, A. dan S. Samsundari. 2005. Parasit dan Penyakit Ikan. Muhammadiyah University Press. Malang. 201 hal.

Irianto, A. 2005. Patologi Ikan Teleostei. Gadjah Mada University Press. Yogyakarta. 256 hal.

Lingga, P. dan H. Susanto. 2003. Ikan Hias Air Tawar Edisi Revisi (Penebar Swadaya. Jakarta). 237 hal.

Prajitno, A. 2005. Diktat Kuliah Parasit dan Penyakit Ikan. Universitas Brawijaya. Malang. 104 hal.

Yildiz, K and A. Kumantas. 2002. Argulus foliaceus infection in a goldfish (Carassius auratus). Israel. 57 (3): 118- 120. 